\title{
PEMBELAJARAN MATEMATIKA MELALUI STRATEGI BERBASIS MASALAH DI KELAS V SDN 04 V KOTO KAMPUNG DALAM KABUPATEN PADANG PARIAMAN
}

\section{ASNIAR}

\section{Abstrak}

Pembelajaran matematika di SD diarahkan untuk menghapal konsep. Guru memberikan informasi dan pengetahuan saja kepada siswa, tanpa mengaplikasikan konsep untuk menyelesaikan masalah. Pembelajaran matematika perlu diperbaiki melalui Strategi Pembelajaran Berbasis Masalah (SPBM). Tujuan penelitian untuk mendeskripsikan pembelajaran matematika menggunakan strategi pembelajaran Berbasis Masalah (SPBM). Penelitian ini menggunakan pendekatan penelitian tindakan kelas dengan dua siklus. Hasil pengamatan terhadap aktivitas guru lebih meningkat dari baik menjadi sangat baik. Hasil belajar siswa juga meningkat dari rata-rata 54,63 menjadi 78,37.

Keyword: pembelajaran matematika, strategi berbasis masalah, SD

Copyright (C) 2016 IICET (Padang - Indonesia) - All Rights Reserved

Indonesian Institute for Counseling, Education and Theraphy (IICET)

\section{PENDAHULUAN}

Matematika adalah suatu ilmu yang berisi simbol-simbol, model, dan konsep-konsep yang berguna dalam kehidupan. Seperti yang dikemukakan oleh Karmawati (2009:1) "matematika merupakan ilmu deduktif, aksiomatik, hirarkis, abstrak, bahasa simbol yang padat arti, dan sebuah sistem matematika yang berisikan model-model yang dapat digunakan untuk mengatasi persoalan-persoalan nyata". Selain itu, matematika dapat membentuk pola pikir matematis yang sistematis, logis, kritis, dan perlu kecermatan. Bidang studi matematika berisi konsep-konsep yang dapat digunakan dalam segala aspek kehidupan yang dapat meningkatkan kemampuan berfikir yang logis dan memberikan kepuasan terhadap usaha memecahkan masalah dalam kehidupan sehari-hari. Oleh sebab itu guru SD harus merancang pembelajaran yang membuat siswa memahami konsep matematika tersebut dan dapat menggunakannya dalam kehidupan.

Agar pembelajaran matematika lebih bermakna bagi siswa, seharusnya dimulai dengan pemberian masalah yang terjadi dalam kehidupan siswa. Seperti dijelaskan oleh Depdiknas (2006:416) "pembelajaran matematika hendaknya dimulai dengan pengenalan masalah yang sering ditemui siswa dalam kehidupan sehari-hari". Hal tersebut berguna agar nantinya siswa mengetahui manfaat matematika dan dapat memecahkan masalah dalam kehidupan sehari-hari. Di dalam pembelajaran matematika, permasalahan dinyatakan dalam bentuk soal cerita. Seperti yang dikemukakan oleh Budhi (2006:2)"soal cerita merupakan soal yang berbentuk cerita tentang sesuatu hal yang berkaitan dengan kehidupan sehari-hari"

Pembelajaran penyelesaian masalah dalam matematika perlu dilakukan secara sistematis dengan pemahaman konsep yang kuat oleh siswa. Hal tersebut tentu tidak lepas dari peran seorang guru yang merupakan faktor penting dalam pembelajaran. Guru harus mengetahui tugas yang dilakukannya dalam membelajarkan matematika agar pembelajaran tersebut menjadi lebih bermakna. Seperti yang dijelaskan oleh Karmawati (2009:3) bahwa tugas seorang guru matematika adalah menyajikan matematika dengan baik, dan harus menguasai bahan kajian matematika yang diajarkan. Namun, penguasaan bahan saja tidak cukup, guru juga perlu menguasai strategi dan pendekatan pembelajaran matematika. Oleh sebab itu, guru harus dapat menciptakan iklim belajar yang kondusif dan dapat memilih strategi pembelajaran yang tepat. Dalam memilih strategi pembelajaran guru harus memperhatikan taraf perkembangan siswa dan karakteristik ilmu matematika tersebut.

Siswa tingkat SD sedang mengalami perkembangan dalam tingkat berfikirnya. Siswa SD kelas rendah, taraf berfikirnya masih pada tahap konkret. Mereka masih kesulitan dalam mamahami konsep-konsep operasi seperti penjumlahan, pengurangan, pembagian, perkalian dan belum bisa diajak berfikir secara deduktif. Sedangkan siswa kelas tinggi (IV, V, VI, dengan usia 11 tahun ke atas) sudah berada pada tahap berfikir 
formal. Siswa sudah bisa berfikir secara deduktif. Oleh sebab itu, untuk mengembangkan pola pikir siswa tersebut guru perlu memilih strategi yang tepat dan sesuai dengan tahap perkembangan berfikir siswa dalam pembelajaran matematika.

Ketepatan guru dalam memilih strategi pembelajaran akan berpengaruh terhadap hasil belajar siswa. Sebagaimana dikemukakan Wina (2008:2) "di dalam pembelajaran antara proses dan hasil belajar berjalan secara seimbang". Proses pembelajaran yang efektif akan meningkatkan hasil belajar yang dicapai siswa. Jadi, penggunaan strategi pembelajaran yang tepat menjadi salah satu penentu keberhasilan belajar.

Berdasarkan hasil pengalaman peneliti dalam proses pembelajaran di kelas V SDN 04 V Koto Kampung Dalam Kabupaten Padang Pariaman, ketika materi tentang perkalian dan pembagian pecahan, guru hanya mengarahkan siswa pada kemampuan menghapal konsep dan informasi tanpa dituntut untuk memahami informasi dan menghubungkandengan kehidupannya sehari-hari.

Apabila siswa diberikan soal yang berupa pemahaman isian singkat, seperti yang peneliti lakukan misalnya $\frac{2}{5}: \frac{1}{5}=\cdots$ siswa berpacu untuk menyelesaikannya. Namun, setelah mereka diberikan masalah kontekstual berbentuk soal cerita yang terjadi dalam kehidupan sehari-hari yang penyelesaiannya memerlukan konsep misalnya Ibu ingin memasak 2 bungkus agar-agar. Agar-agar yang telah dimasak tersebut akan dimasukkan ke dalam cetakan. Masing- masing cetakan berisi $\frac{2}{3}$ bungkus agar-agar. Berapa buah cetakan yang diperlukan untuk mencetak agar-agar ibu tersebut?

Dalam menyelesaikan permasalahan tersebut, siswa tidak tahu bagaimana dan menggunakan cara apa untuk menyelesaikannya. Hal tersebut dikarenakan mereka tidak mengetahui dengan pasti gambaran besar masalah. Namun, siswa takut untuk bertanya bahkan cenderung tidak tahu apa yang akan ditanyakan. Sehingga menyebabkan siswa pintar secara teoritis akan tetapi miskin aplikasi konsep tersebut dalam kehidupan sehari-hari.

Merujuk dari permasalahan yang telah dikemukakan, peneliti tertarik untuk menggunakan strategi pembelajaran yang menuntut aktivitas mental siswa untuk lebih memahami suatu konsep pembelajaran. Aktivitas ini dilakukan melalui Strategi Pembelajaran Berbasis Masalah (SPBM). Nurhadi (2003:55) menyatakan bahwa "pembelajaran berbasis masalah adalah suatu pembelajaran yang menggunakan masalah dunia nyata sebagai suatu konteks bagi siswa untuk belajar tentang cara berfikir kritis dan keterampilan pemecahan masalah, serta untuk memperoleh pengetahuan dan konsep yang esensial dari materi pelajaran".

SPBM menekankan pada proses penyelesaian masalah yang dihadapi secara ilmiah, dan memiliki ciri utama yaitu: Merupakan serangkaian aktivitas, dimana SPBM tidak mengharapkan siswa hanya sekedar mendengarkan, mencatat, kemudian menghapal materi pelajaran. Akan tetapi, melalui SPBM siswa aktif berfikir kreatif dan kritis yang memungkinkan siswa mempelajari masalah secara sistematis, berkomunikasi, mencari dan mengolah data, dan akhirnya menyimpulkan. Selain itu SPBM mengarahkan pembelajaran untuk menyelesaikan masalah. Pembelajaran berpusat pada masalah. Dari masalah tersebutlah siswa belajar bagaimana untuk menyelesaikannya. Artinya tanpa masalah tidak mungkin ada proses pembelajaran. Pemecahan masalah dilakukan dengan menggunakan pendekatan berfikir secara ilmiah untuk mencapai pemahaman yang lebih baik dan menyebabkan peningkatan hasil belajar siswa (Wina, 2008:214).

Peneliti tertarik untuk mengkaji lebih lanjut tentang "Pembelajaran Matematika Melalui Strategi Pembelajaran Berbasis Masalah Di Kelas V SDN 04 V Koto Kampung Dalam Kabupaten Padang Pariaman.” Bertolak dari latar belakang yang telah diuraikan, rumusan masalah penelitian secara umum adalah bagaimanakah pembelajaran Matematika Melalui Strategi Berbasis Masalah (SPBM) di kelas V SDN 04 V Koto Kampung Dalam Kabupaten Padang Pariaman? Penelitian ini bertujuan untuk mendiskripsikan pembelajaran Matematika melalui strategi berbasis masalah (SPBM) di kelas V SDN 04 V Koto Kampung Dalam Kabupaten Padang Pariaman.

\section{METODELOGI PENELITIAN}

Penelitian ini dilaksanakan di SDN 04 V Koto Kampung Dalam Kabupaten Padang Pariaman. Subjek penelitian merupakan siswa kelas V semester II SDN 04 V Koto Kampung Dalam Kabupaten Padang Pariaman yang berjumlah 27 orang. Adapun yang terlibat dalam penelitian yaitu peneliti sebagai guru dan kepala sekolah sebagai observer. Penelitian ini dilaksanakan pada semester Januari-Juni 2012.

Pendekatan yang digunakan yaitu penelitian tindakan kelas (PTK). Suharsimi (2006:3) menyatakan bahwa "Penelitian tindakan kelas merupakan suatu pencermatan terhadap kegiatan belajar berupa sebuah tindakan, yang dimunculkan dan terjadi dalam sebuah kelas secara bersama”. Pendapat ini diperkuat oleh 
Kasihani (1999: 15) “PTK merupakan penelitian tindakan dalam bidang pendidikan yang dilaksanakan dalam kawasan kelas dengan tujuan memperbaiki dan atau meningkatkan kualitas pembelajaran". Penelitian tindakan kelas dilaksanakan sebanyak dua siklus. Setiap siklus terdiri dari dua pertemuan. Data penelitian ini adalah: aktivitas guru dan siswa dalam proses pembelajaran dan hasil belajar. Data dianalisis menggunakan pendekatan kuantitatif dengan teknik persentase.

\section{HASIL DAN PEMBAHASAN PENELITIAN HASIL PENELITIAN \\ Siklus I \\ Pertemuan I \\ Perencanaan}

Pelaksanaan siklus I pertemuan 1 ini dilakukan pada tanggal 2 Juni 2012 pada pukul 07.30 sampai $09.15 \mathrm{Wib}$, guru dalam merencanakan tindakan membuat persiapan yang terdiri dari Rencana Pelaksanaan Pembelajaran (RPP) dan Lembar Kerja Siswa (LKS). Materi pembelajaran yang dilaksanakan pada siklus I pertemuan I adalah pembelajaran mengalikan bilangan asli dengan pecahan. Kompetensi dasar yang ingin dicapai pada materi ini yaitu mengali dan membagi berbagai bentuk pecahan. Indikator yang ingin dicapai adalah menyelesaikan masalah yang berhubungan dengan perkalian bilangan asli dengan pecahan.

\section{Pelaksanaan Tindakan}

Guru meminta siswa berdoa dan mencek kehadiran mereka. Setelah itu, guru melakukan tanya jawab tentang operasi perkalian bilangan asli dengan pecahan. Guru menyampaikan tujuan pembelajaran. Pada kegiatan inti, guru memajangkan kertas cart yang berisi permasalahan kontekstual yang berbentuk soal cerita yang berhubungan dengan perkalian bilangan asli dengan pecahan dan meminta siswa membaca permasalahan. Kemudian guru melakukan tanya jawab dengan siswa tentang permasalahan tersebut. Guru membagi siswa menjadi 5 kelompok, setiap kelompok mendapatkan 5 buah pita berbeda warna, solatip, gunting LKS untuk didiskusikan siswa. Siswa menerima alat dan bahan yang diberikan guru. Setelah siswa menerima alat dan bahan yang diberikan, guru meminta masing-masing kelompok membaca LKS dan bertanya apabila ada keraguan dalam LKS. Masing-masing kelompok membaca LKS yang diberikan guru.

Kemudian pembelajaran dilanjutkan dengan tahap melakukan penyelidikan individual maupun kelompok. Dengan menggunakan alat dan bahan yang telah diberikan tersebut, siswa melakukan penyelidikan dengan menciptakan suasana seperti dalam masalah. dengan mengikuti langkah-langkah yang terdapat dalam LKS. Guru kemudian menanyakan kepada siswa bagaimana cara mencari panjang pita kakak seluruhnya. Sesuai langkah-langkah yang terdapat dalam LKS, siswa menandai panjang masing pita kakak kemudian menggunting panjang masing-masing pita kakak. Untuk mencari panjang seluruh pita kakak siswa melekatkan panjang masing masing pita kakak kemudian mengukur panjang seluruh pita kakak. Dengan kegiatan tersebut siswa mendapatkan panjang seluruh pita kakak. Ketika siswa berdiskusi, guru memberikan bimbingan kepada tiap-tiap kelompok terutama kelompok yang mengalami kesulitan.

Tahap mengembangkan dan menghasilkan hasil karya, kegiatan yang dilakukan guru yaitu membimbing siswa membuat model dan mengisi LKS. Setelah selesai berdiskusi, guru meminta masingmasing kelompok melaporkan hasil diskusi ke depan kelas. Tahap terakhir yaitu tahap menganalisis dan mengevaluasi proses pemecahan masalah, guru meminta kelompok menanggapi hasil diskusi kelompok lainnya. Kemudian bersama-sama mengevaluasi hasil pemecahan masalah yang telah didiskusikan.

Di akhir kegiatan inti guru memberikan sebuah contoh soal kepada masing-masing kelompok dan meminta mengerjakan soal tersebut. setelah selesai, guru membahas soal tersebut secara bersama-sama dan menemukan jawaban akhir soal tersebut. Mengakhiri kegiatan, guru membimbing siswa merangkum materi pelajaran dan memberikan tes kepada masing-masing individual siswa.

\section{Siklus I pertemuan II \\ a. Tahap Perencanaan}

Dalam perencanaan pertemuan II siklus I ini dilakukan pada hari Kamis,4 juni 2012 pukul 07.3009.15. Guru dalam merencanakan tindakan membuat persiapan yang terdiri dari RPP dan LKS. Sedangkan instrumen pengumpulan data yang digunakan adalah instrumen pengamatan RPP, dan lembar observasi aktivitas guru dan siswa dalam pembelajaran. Keseluruhan instrumen yang peneliti cantumkan sebelumnya terdapat pada lampiran 7-11. Materi pembelajaran yang dilaksanakan pada pertemuan 2 siklus 1 adalah mengalikan pecahan dengan pecahan. Kompetensi dasar yang ingin dicapai pada materi ini yaitu mengali dan membagi berbagai bentuk pecahan. Sedangkan indikator yang ingin dicapai pada pertemuan 2 ini adalah 
menyelesaikan masalah kontekstual yang berhubungan dengan perkalian pecahan dengan pecahan. Untuk mencapai indikator yang telah ditentukan, peneliti selaku praktisi menggunakan SPBM dengan mengikuti langkah-langkah yang telah ditentukan.

\section{b. Tahap Pelaksanaan Tindakan}

Pertemuan II pada siklus I ini dilaksanakan pada hari Kamis tanggal 4 Juni 2012 mulai pukul 07.3009.15, pembelajaran untuk pertemuan I berlangsung selama 105 menit. Pelaksanaan pembelajaran pertemuan 2 ini sesuai dengan rencana yang telah ditetapkan.

Pada pelaksanaan tindakan, peneliti bertindak sebagai guru. mengawali tindakan, peneliti mengucapkan salam dan siswa menjawab salam yang diucapkan guru. Kemudian menyiapkan kondisi kelas, menyuruh siswa berdoa serta mencek kehadiran siswa. Untuk mengingatkan siswa pada pelajaran yang telah dipelajari, guru melakukan tanya jawab dengan siswa tentang operasi perkalian pecahan dengan pecahan. Setelah itu, guru menyampaikan tujuan pembelajaran yaitu siswa mampu mengalikan bilangan asli dengan pecahan. Siswa mendengarkan guru dalam menyampaikan tujuan pembelajaran.

Pada kegiatan inti, tahap mengorientasikan siswa pada masalah, kegiatan yang dilakukan guru yaitu memajangkan kertas cart yang berisi permasalahan kontekstual yang berbentuk soal cerita yang berhubungan dengan perkalian pecahan dengan pecahan dan meminta siswa membaca permasalahan. Permasalahan yang diberikan guru yaitu Luas kebun pak Ahmad $\frac{3}{4}$ dari luas kebun pak Budi. Jika luas kebun pak Budi $\frac{1}{4}$ hektar. Berapa hektar luas kebun pak Ahmad?. Kemudian guru melakukan tanya jawab tentang apa yang diketahui dan ditanya tentang permasalahan tersebut. Dari pertanyaan yang diberikan guru hanya sebagian siswa yang aktif menjawab dan bertanya.

Pada tahap mengorganisasikan siswa untuk belajar kegiatan yang dilakukan guru yaitu membagi siswa menjadi 5 kelompok dan pada tiap-tiap anggota kelompok, guru memberikan alat dan bahan yang diperlukan untuk menyelesaikan masalah yaitu kertas karton ukuran persegi dengan panjang sisi $20 \mathrm{~cm}$. Setelah itu guru meminta masing-masing kelompok membaca LKS dan bertanya apabila ada keraguan dalam LKS. Dan memotivasi masing-masing kelompok untuk bekerjasama dalam berdiskusi. Namun tampak siswa masih kurang termotivasi untuk belajar. Hal tersebut tampak dari masih adanya siswa yang bergelut dengan temannya.

Pembelajaran dilanjutkan dengan tahap melakukan penyelidikan individual maupun kelompok. Dengan menggunakan alat dan bahan yang telah diberikan tersebut, siswa melakukan penyelidikan dengan menciptakan suasana seperti dalam masalah. dengan mengikuti langkah-langkah yang terdapat dalam LKS. Guru menanyakan kepada siswa bagaimana cara mencari luas berapa hektar luas tanah ayah. Sesuai dengan langkah - langkah yang terdapat dalam LKS, siswa membagi karton menjadi perempatan dan mengarsir luas kebun pak Budi, kemudian mengambil sebuah kertas transparan dam mengarsir luas kebun pak ahmad lalu mendempetkan keduanya. Dari hasil pendempetan tersebut siswa menemukan berapa luas kebun pak Ahmad. Kemudian kegiatan dilanjutkan dengan tahap mengembangkan dan menghasilkan hasil karya, kegiatan yang dilakukan guru yaitu membimbing siswa membuat model dan mengisi LKS. Setelah selesai berdiskusi, guru meminta masing- masing kelompok melaporkan hasil diskusi ke depan kelas. Guru meminta salah satu kelompok menuliskan hasil diskusinya kepapan tulis, kemudian meminta kelompok lain menanggapi hasil diskusi kelompok tersebut.

Tahap terakhir yaitu tahap menganalisis dan mengevaluasi proses pemecahan masalah, guru meminta kelompok lain menanggapi hasil diskusi kelompok lain. kemudian menyimpulkan hasil akhir penyelesaian masalah. Kemudian bersama-sama mengevaluasi hasil pemecahan masalah yang telah didiskusikan. Mengakhiri kegiatan, guru membimbing siswa merangkum materi pelajaran dan memberikan tes kepada masing-masing individual siswa. Dan siswa pun mengerjakan tes yang diberikan guru, namun dalam mengerjakan tes masih ada siswa yang mencontek jawaban siswa yang lain.

c. Tahap pengamatan

Hasil pengamatan yang dilakukan pengamat, keberhasilan tindakan guru pada pada pelaksanaan perencanaan siklus 1 pertemuan 2 mencapai keberhasilan sangat baik dengan skor yang didapatkan 51 dari skor maksimal yaitu 64. Sehingga persentase keberhasilan pelaksanaan pembelajaran yang dilakukan guru dengan menggunakan Strategi pembelajaran berbasis masalah yaitu 82,26 \%. Keberhasilan aktivitas siswa pada siklus 1 pertemuan 1 mencapai keberhasilan baik dengan perolehan skor 49 dari jumlah skor maksimum 
yaitu 64. Sehinga persentase keberhasilan aktivitas siswa pada pembelajaran perkalian bilangan bulat dengan pecahan melalui strategi pembelajaran berbasis masalah yaitu 76,56\%.

Keberhasilan siswa dalam pembelajaran penyelesaian masalah dalam pembelajaran tentang perkalian pecahan dapat dilihat dari tuntas tidaknya materi, yang dapat dilihat dari hasil belajar siswa pada siklus I yang terdapat pada lampiran 12. Pada hasil belajar siswa tersebut rata-rata kelas yang didapatkan yaitu 75,4.

\section{Refleksi.}

Berdasarkan hasil belajar pada pertemuan 1 dan II, hasil belajar pada siklus I mencapai nilai rata-rata kelas 74,35 dan mencapai ketuntasan belajar $66,67 \%$, karena masih ada 9 orang anak yang belum tuntas dalam belajar. Hasil belajar pada siklus I tersebut belum mencapai standar ketuntasan yang ditetapkan sekolah yaitu 70\%. Melalui hasil diskusi dengan guru kelas, maka diperoleh hal-hal sebagai berikut:

1) Penyajian materi dengan menggunakan SPBM sudah sesuai dengan rencana namun waktu yang digunakan untuk berdiskusi pada siklus 1 terlalu panjang sehingga waktu untuk melaksanakan tes sedikit, sehingga siswa terburu-buru mengerjakan soal.

2) Pada saat diskusi terdapat beberapa pertanyaan guru yang kurang dipahami oleh siswa, sehingga ada beberapa kelompok yang kurang memahami permasalahan yang didiskusikan.

3) Masih banyak siswa yang belum aktif terlibat dalam pembelajaran khususnya sewaktu melakukan diskusi hanya didominasi oleh beberapa orang siswa saja.

4) Siswa kesulitan dalam pengisian LKS, hal ini disebabkan Karena siswa kurang mengerti dalam penggunaan media. Untuk itu peneliti perlu memberikan penjelasan tentang penggunaan media.

5) Masih ada 3 kelompok yang kesulitan mengaplikasikan kegiatan konkret ke semi konkrit.

6) Hasil tes siklus I menunjukkan belum keseluruhan siswa memahami materi yang diberikan. Masih ada beberapa siswa yang masih mendapatkan nilai tes di bawah rata-rata. Setelah ditanyakan kepada siswa ternyata beberapa dari mereka tidak memahami permasalahan disamping itu mereka tidak terlalu konsentrasi karena didesak waktu oleh guru.

Berdasarkan pengamatan dan tes, tujuan pembelajaran yang diharapkan pada pembelajaran siklus I belum tercapai dengan baik terdapat 9 orang anak yang belum mencapai ketuntasan belajar yang telah ditetapkan. ketuntasan yang ditetapkan sekolah yaitu 70\%. Dengan demikian pembelajaran penyelesaian masalah dengan menggunakan SPBM dilanjutkan pada siklus II.

\section{Siklus II Pertemuan I}

\section{Perencanaan.}

Hasil analisis refleksi pada siklus I menunjukkan subjek penelitian belum mencapai tujuan pembelajaran khusus yang diharapkan. Karena itu pembelajaran dilanjutkan dengan siklus II. Pembelajaran siklus II diberikan agar siswa dapat memahami lebih lanjut tentang materi membagi bilangan asli dengan pecahan. Pembelajaran siklus II dilaksanakan dalam dua kali pertemuan dengan alokasi waktu 6 x 35 menit. Pada pertemuan 1 akan dilaksanakan hari Selasa tanggal 9 Juni 2012 dengan alokasi 3 x 35 menit. Kompetensi dasar yang akan diajarkan adalah mengali dan membagi berbagai bentuk pecahan. Dengan indikator sebagai berikut: menyelesaikan masalah yang berhubungan dengan pembagian bilangan asli dengan pecahan. Agar peneliti dapat melaksanakan tugasnya dengan baik, maka peneliti menyiapkan RPP, lembar pengamatan aktivitas guru dan siswa dalam pembelajaran, dan lembaran pengamatan RPP. Keseluruhan instrumen yang peneliti cantumkan terdapat pada lampiran 13-18. Pada pelaksanaan siklus II pertemuan I ini, Guru menggunakan SPBM didampingi metode diskusi, tanya jawab, ceramah dan penugasan.

\section{Pelaksanaan}

Pertemuan I pada siklus 2 ini dilaksanakan pada hari selasa tanggal 9 Juni 2012 mulai pukul 07.3009.15, pembelajaran untuk pertemuan I berlangsung selama 105 menit. Pelaksanaan pembelajaran pertemuan I ini sesuai dengan rencana yang telah ditetapkan. Pada pelaksanaan tindakan peneliti bertindak sebagai guru. Mengawali tindakan, peneliti mengucapkan salam. Dan siswa menjawab salam yang diucapkan guru, Kemudian siswa menyiapkan kondisi kelas, menyuruh siswa berdoa serta mencek kehadiran siswa, setelah itu guru menginagtkan pembelajaran tentang operasi pembagian bilangan asli dengan pecahan. Kemudian menyampaikan tujuan pembelajaran yang akan dipelajari yaitu membagi bilangan asli dengan pecahan.

Pada kegiatan inti, tahap mengorientasikan siswa pada masalah, kegiatan yang dilakukan guru yaitu memajangkan kertas cart yang berisi permasalahan kontekstual yang berbentuk soal cerita yang berhubungan dengan perkalian bilangan asli dengan pecahan dan meminta siswa membaca permasalahan. Kemudian guru melakukan tanya jawab dengan siswa tentang apa yang diketahui dan ditanya dalam permasalahan tersebut. dan siswa pun sudah mulai aktif menjawab pertanyaan guru. 
Pada tahap mengorganisasikan siswa untuk belajar kegiatan yang dilakukan guru yaitu membagi siswa menjadi 5 kelompok dan pada tiap-tiap anggota kelompok, guru memberikan alat dan bahan yang diperlukan untuk menyelesaikan masalah yaitu 3 buah kue kepada masing-masing kelompok. Setelah itu guru meminta masing-masing kelompok membaca LKS dan bertanya apabila ada keraguan dalam LKS. Dan siswa menerima alat dan bahan yang diberikan guru. Kemudian pembelajaran dilanjutkan dengan tahap melakukan penyelidikan individual maupun kelompok. Dengan menggunakan alat dan bahan yang telah diberikan tersebut, siswa melakukan penyelidikan dengan menciptakan suasana seperti dalam masalah. yaitu dengan mengikuti langkah-langkah yang terdapat dalam LKS. Guru menanyakan bagaimana cara mencari banyak teman Rina yang mendapatkan kue, sesuai dengan langkah-langkah yang terdapat dalam LKS, siswa membagi kue dengan ukuran menjadi $\frac{1}{4}$ untuk masing-masing bagian kue. Dan menghitung berapa buah bagian kue yang akan dibagikan kepada teman-teman Rina. Ketika siswa berdiskusi, guru memberikan bimbingan kepada tiap-tiap kelompok terutama kelompok yang mengalami kesulitan.

Tahap mengembangkan dan menghasilkan hasil karya, kegiatan yang dilakukan guru yaitu siswa membuat model dari kegiatan tersebut dan guru membimbing siswa mengisi LKS. Setelah selesai berdiskusi, guru meminta masing kelompok melaporkan hasil diskusi ke depan kelas. Tahap terakhir yaitu tahap menganalisis dan mengevaluasi proses pemecahan masalah, guru meminta kelompok menanggapi hasil diskusi kelompok lain. Kemudian bersama-sama mengevaluasi hasil pemecahan masalah yang telah didiskusikan. Mengakhiri kegiatan, guru membimbing siswa merangkum materi pelajaran dan memberikan tes kepada masing-masing individual siswa.

\section{Pengamatan}

Hasil pengamatan yang telah dilakukan, aktifitas guru mencapai keberhasilan sangat baik. Dengan skor yang diperoleh yaitu 53 dan persentase keberhasilan aktivitas guru yaitu $82,81 \%$ terlihat pada lampiran 15. Sedangkan keberhasilan aktivitas siswa mencapai keberhasilan baik dengan skor yang diperoleh yaitu 53 dan persentase yang sama dengan keberhasilan aktivitas guru. untuk lebih jelasnya terlihat pada lampiran 16. Hasil belajar siswa pada pertemuan I mencapai nilai rata-rata kelas 81,48 . Untuk lebih jelasnya dapat dilihat dalam lampiran 18.

\section{Siklus II pertemuan II \\ Perencanaan.}

Pertemuan II pada siklus II ini akan dilaksanakan pada hari Kamis tanggal 11 Juni 2012 mulai pukul 07.30-09.15, pembelajaran untuk pertemuan II berlangsung selama 105 menit. Pelaksanaan pembelajaran pertemuan I ini sesuai dengan rencana yang telah ditetapkan. Kompetensi dasar yang akan diajarkan adalah mengali dan membagi berbagai bentuk pecahan Dengan indikator sebagai berikut: Menyelesaikan masalah tentang pembagian pecahan dengan pecahan. Agar peneliti dapat melaksanakan tugasnya dengan baik, maka peneliti menyiapkan rencana pelaksanaan pembelajaran, lembar pengamatan aktivitas guru dan siswa dalam pembelajaran, dan lembaran pengamatan RPP.

\section{Pelaksanaan}

Pertemuan II pada siklus II ini dilaksanakan pada hari Kamis tanggal 11 Juni 2012 mulai pukul 07.30-09.15, pembelajaran untuk pertemuan II berlangsung selama 105 menit. Pelaksanaan pembelajaran pertemuan II ini sesuai dengan rencana yang telah ditetapkan. Pada pelaksanaan tindakan peneliti bertindak sebagai guru. Mengawali tindakan, peneliti mengucapkan salam. Kemudian menyiapkan kondisi kelas, menyuruh siswa berdoa serta mencek kehadiran siswa, menyampaikan topik yang akan dipelajari yaitu membagi pecahan dengan pecahan. Barulah guru menyampaikan tujuan pembelajaran.

Pada kegiatan inti, tahap mengorientasikan siswa pada masalah, kegiatan yang dilakukan guru yaitu memajangkan kertas cart yang berisi permasalahan kontekstual yang berbentuk soal cerita yang berhubungan dengan pembagian pecahan dengan pecahan dan meminta siswa membaca permasalahan. Permasalahan yang diberikan guru yaitu pak Bambang memiliki tanah dengan luas $\frac{3}{4}$ hektar. Tanah pak Bambang akan ditanami bermacam-macam tanaman yang berbeda, jika luas masing-masing tanaman adalah $\frac{1}{8}$ hektar. Berapa macam tanaman yang dapat ditanam di tanah tersebut? Kemudian guru melakukan tanya jawab dengan siswa tentang permasalahan tersebut. dan siswapun menjawab pertanyaan yang diberikan guru.

Pada tahap mengorganisasikan siswa untuk belajar kegiatan yang dilakukan guru membagi siswa menjadi 5 kelompok. Pada tiap-tiap anggota kelompok, guru memberikan alat dan bahan yang diperlukan untuk menyelesaikan masalah yaitu 1 buah kertas karton. Setelah itu guru meminta masing-masing kelompok membaca LKS dan bertanya apabila ada keraguan dalam LKS. Pada tahap ini, siswa menerima alat dan 
bahan yang diberikan guru.Kemudian pembelajaran dilanjutkan dengan tahap melakukan penyelidikan individual maupun kelompok. Dengan menggunakan alat dan bahan yang telah diberikan tersebut, siswa melakukan penyelidikan dengan menciptakan suasana seperti dalam masalah. yaitu dengan mengikuti langkah-langkah yang terdapat dalam LKS. Guru menanyakan bagaimana cara mencari berapa macam tanaman yang akan ditanam ayah ditanah tersebut.

Sesuai dengan langkah-langkah yang terdapat dalam LKS siswa membuat gambar sebuah persegi dengan ukuran sisi $20 \mathrm{~cm}$. kemudian mengarsir luas tanah yang dimiliki pak Bambang kemudian siswa membagi tanah tersebut menjadi seperdelapanan, dan meminta siswa mewarnai seperdelapanan yang terkena arsiran dengan warna yang berbeda pada setiap bagian seperdelapanan dan meminta siswa menggunting bagian yang telah diwarnai dan menghitung warna yang terbentuk. Dan banyak warna merupakan banyak tanaman yangakan ditanam dikebun tersebut.

Tahap mengembangkan dan menghasilkan hasil karya, kegiatan yang dilakukan guru yaitu membimbing siswa membuat model dan mengisi LKS. Setelah selesai berdiskusi, guru meminta masingmasing kelompok melaporkan hasil diskusi ke depan kelas. Tahap terakhir yaitu tahap menganalisis dan mengevaluasi proses pemecahan masalah guru meminta kelompok lain menanggapi hasil diskusi kelompok lain. Kemudian bersama-sama mengevaluasi hasil pemecahan masalah yang telah didiskusikan. Mengakhiri kegiatan, guru membimbing siswa merangkum materi pelajaran dan memberikan tes kepada masing-masing individual siswa.

\section{Tahap pengamatan}

Keberhasilan guru dalam pelaksanaan tindakan mencapai keberhasilan sangat baik, dengan skor yang diperoleh 57. Dan persentase keberhasilan mencapai 89,06\% terlihat dari lampiran 21. Keberhasilan aktivitas siswa dalam pembelajaran mencapai keberhasilan sangat baik dengan perolehan skor 56. Dan persentase keberhasilan mencapai $87,5 \%$ seperti tergambar pada lampiran 22. Hasil belajar siswa pada pertemuan II mencapai nilai rata-rata 79,63 .

\section{Tahap refleksi}

Kegiatan refleksi dilakukan secara kolaboratif antara peneliti dengan kepala sekolah, refleksi dilakukan setelah pertemuan I dan II selesai. Refleksi tindakan siklus II ini mencakup refleksi terhadap perencanaan, pelaksanaan, dan hasil belajar yang diperoleh oleh siswa. Refleksi terhadap perencanaan yakni sebagai berikut: dilihat dari hasil paparan siklus II diketahui bahwa perencanaan pembelajaran terlaksana dengan baik, dan langkah pembelajaran telah dilaksanakan dengan baik. Hasil observasi tentang perencanaan, pelaksanaan dan evaluasi siswa pada siklus II ini mengindikasikan bahwa penerapan SPBM sudah terlaksana dengan baik. Secara lengkapnya hasil observasi tentang perencanaan, pelaksanaan dan evaluasi afektif, kognitif, dan psikomotor siswa dapat dilihat pada lampiran 13 - 24.

Hasil belajar siswa pada siklus II ini meningkat dibandingkan dengan hasil belajar pada siklus I dengan perbandingan 74,35 pada siklus I dan pada siklus II meningkat menjadi 80,55. Ketuntasan belajar siswa pada siklus I mencapai $66,67 \%$ karena ada 9 orang siswa yang tidak tuntas dalam belajar dan siklus II meningkat menjadi $77,78 \%$ karena ada 6 orang siswa yang tidak mencapai standar ketuntasan yang ditetapkan. Hasil belajar siswa pada siklus II tersebut telah mencapai standar ketuntasan yang telah ditetapkan sekolah yaitu 70\%.. Dan dapat disimpulkan bahwa peneliti dalam pembelajaran siklus II telah melaksanakan tugas dengan baik.. Dengan demikian penelitian ini berhenti pada siklus II. Berdasarkan hasil diskusi dengan guru kelas, maka diperoleh hal-hal sebagai berikut:

1. Penyajian materi dengan menggunakan SPBM sudah sesuai dengan rencana dan waktu yang digunakan untuk berdiskusi sudah dapat dimanfaatkan siswa dengan baik.

2. Dalam berdiskusi $75 \%$ siswa sudah aktif manjawab dan bertanya, dan bekerja dalam kelompok.

3. Kelompok terlihat sudah tidak kesulitan mengaplikasikan kegiatan konkret ke semi konkrit.

4. Hasil tes siklus I menunjukkan siswa sudah memahami materi yang diberikan. Sudah $75 \%$ siswa yang tuntas dalam belajar. Walaupun masih ada beberapa siswa yang masih mendapatkan nilai tes di bawah rata-rata.

\section{PEMBAHASAN}

\section{Pembahasan siklus I.}

Perencanaan yang dibuat pada siklus 1 sudah baik. Terlihat dari penilaian perencanaan yang telah dinilai oleh pengamat mencapai keberhasilan baik. Pelaksanaan pembelajaran yang aktif dan menyenangkan sangat dibutuhkan oleh siswa Sekolah Dasar, pembelajaran yang menyenangkan itu dapat dilihat pada saat 
siswa bekerja sama dalam kelompok (Wina, 2008:217). Di dalam kelompok siswa saling tolong menolong, dan siswa dapat dengan mudah memahami materi pelajaran, sesuai dengan rencana pembelajaran berbasis masalah yang dirancang sendiri oleh peneliti, observer mengamati pelaksanaan tindakan yang peneliti lakukan dalam pembelajaran matematika dengan SPBM dengan langkah-langkah sebagai berikut :

1. Mengorientasikan siswa pada masalah

Peneliti memajangkan kertas cart berisi permasalahan kontekstual yang berhubungan dengan mengali bilangan asli dengan pecahan. Kemudian, meminta siswa membaca dan memahami masalah dengan melakukan tanya jawab tentang apa yang diketahui dan ditanya dalam masalah. namun dalam melakukan tanya jawab guru kurang menanggapi berbagai jawaban siswa dan kurang memberikan penghargaan kepada siswa yang mau menjawab. Siswa juga terlihat masih malu untuk menjawab pertanyaan-pertanyaan guru. Dan masih menjawab pertanyaan guru secara bersama-sama/ klasikal. Dari 27 siswa yang aktif bertanya dan menjawab pertanyaan guru hanya beberapa orang siswa saja. sedangkan yang lain hanya diam dan bergelut dengan temannya.

2. Mengorganisasikan siswa untuk belajar

Guru membagi siswa menjadi beberapa kelompok dan membagikan seperangkat alat yang digunakan untuk menyelesaikan masalah. namun guru kurang memotivasi siswa untuk aktif dan bekarja sama dalam kelompok. Untuk mempermudah siswa berdiskusi, guru membagikan LKS kepada masing- masing kelompok dan meminta siswa membaca dan memahami isi LKS. Namun dalam melakukan diskusi masih terlihat beberapa orang siswa yang bergurau dengan temannya. Dan dalam berdiskusi hanya beberapa anggota kelompok saja yang bekerja sedangkan yang lainnya hanya duduk dan mengganggu teman. Dari diskusi kelompok tersebut masih ada siswa yang kurang bertanggung jawab terhadap hasil diskusinya.

3. Membimbing penyelidikan individual atau kelompok

Siswa dibimbing berdiskusi untuk menyelesaikan masalah. Guru dan siswa melakukan tanya jawab tentang apa yang diketahui dan ditanya dalam permasalahan tersebut. dalam melakukan tanya jawab tersebut hanya beberapa orang siswa yang aktif menjawab pertanyaan guru dan bertanya. Setelah itu, siswa dibimbing melakukan penyelidikan dengan menggunakan alat dan bahan yang telah disediakan.

Dengan alat dan bahan tersebut diharapkan siswa dapat memanipulasi alat guna mencari langkahlangkah penyelesaian masalah. Siswa dibimbing mengaplikasikan kegiatan dengan tahapan konkret, semi konkret dan abstrak sesuai dengan langkah-langkah yang terdapat dalam LKS. Namun hanya beberapa orang saja yang bekerja dalam kelompok dan siswa kurang berhati-hati dalam melakukan pengujian. Dalam kegiatan tersebut siswa kebanyakan dibimbing oleh guru, dan siswa kesulitan dalam memahami permasalahan yang mengaplikasikannya dalam dunia nyata karena mereka belum terbiasa dengan pembelajaran tersebut.

4. Mengembangkan dan menyajikan hasil karya

Setelah siswa memanipulasi alat dan bahan yang disediakan, dan telah membuat model matematika dari permasalahan tersebut. Guru membimbing siswa mengisikan hasil kegiatan pada LKS. Namun dalam mengisi LKS siswa kesulitan mengaplikasikan kegiatan pada tahap konkrit yang telah dilakukannya menjadi semi konkrit. Masih ada 2 kelompok yang belum benar membuat gambar dari kegiatan yang dilakukannya. Kemudian siswa menyelesaikan masalah sesuai dengan langkah-langkah atau alternative pemecahan masalah yang telah direncanakan. Setelah selesai baru kemudian masing-masing kelompok melaporkan hasil diskusinya dan kelompok lain memberikan tanggapan. Namun dari 5 kelompok hanya 2 kelompok yang mau memberikan tanggapan. Hal tersebut diakibatkan karena siswa belum terbiasa berdiskusi dalam pembelajaran.

5. Menganalisa dan mengevaluasi proses pemecahan masalah.

Setelah masing-masing kelompok melaporkan hasil diskusinya, guru bersama siswa mengoreksi pemecahan masalah apakah tidak ada kesalahan dalam mengoperasikan angka dan lain-lain. Setelah itu, guru dan siswa bersama-sama menyimpulkan hasil akhir penyelesaian masalah dan guru memberikan penegasan terhadap hasil pemecahan masalah.

Hasil diskusi peneliti dengan kepala sekolah, maka diperoleh hal-hal sebagai berikut:

1. Penyajian materi dengan menggunakan SPBM sudah sesuai dengan rencana namun waktu yang digunakan untuk berdiskusi siklus 1 terlalu panjang sehingga waktu untuk melaksanakan tes sedikit, sehingga siswa terburu-buru mengerjakan soal.

2. Kurangnya rasa tangung jawab di dalam diskusi. Dalam kelompok hanya beberapa orang siswa saja yang ikut bekerja, sedangkan yang lainnya hanya duduk karena guru kurang memberikan motivasi kepada siswa untuk bekerjasama dalam kelompok. Sehingga siswa yang ikut menulis saja yang aktif. 
3. Pada saat diskusi terdapat beberapa pertanyaan guru yang kurang dipahami oleh siswa, sehingga ada beberapa kelompok yang kurang memahami permasalahan yang didiskusikan.

4. Masih banyak siswa yang belum aktif terlibat dalam pembelajaran khususnya sewaktu melakukan diskusi hanya didominasi oleh $50 \%$ orang siswa saja. dan yang aktif menjawab pertanyaan hanya sebahagian kecil saja.

5. Masih ada 3 kelompok yang kesulitan mengaplikasikan kegiatan konkret ke semi konkrit.

6. Hasil tes siklus I menunjukkan belum keseluruhan siswa memahami materi yang diberikan. Masih ada beberapa siswa yang masih mendapatkan nilai tes di bawah rata-rata. Setelah ditanyakan kepada siswa ternyata banyak yang menjawab soal yang diberikan guru sulit dan mereka tidak memahami permasalahan disamping itu mereka tidak terlalu konsentrasi karena didesak waktu oleh guru.

Pelaksanaan tindakan pada siklus 1 pada aspek guru mencapai keberhasilan baik dan pada aktivitas siswa mencapai keberhasilan baik. Nilai rata-rata hasil belajar siswa pada pertemuan 1 yaitu 73,5.dan pertemuan II meningkat menjadi 75,4 Namun masih ada 9 orang siswa yang memperoleh nilai dibawah ratarata. Berdasarkan hasil belajar pada pertemuan 1 dan II maka hasil belajar pada siklus satu mencapai keberhasilan baik dengan nilai rata-rata 74,35. Hasil belajar tersebut mengalami peningkatan dibanding hasil belajar sebelum menggunakan strategi pembelajaran berbasis masalah. namun hasil belajar siswa tersebut hanya mencapai ketuntasan belajar 66,67 \% dan belum mencapai standar ketuntasan yang diharapkan sekolah yaitu $70 \%$. Untuk itu, peneliti melanjutkan penelitian pada siklus II.

Pembahasan siklus II.

Guru harus dapat memperhatikan perbedaan yang ada pada siswa karena tiap individu mempunyai karakteristik yang berbeda. Menurut Rochman Natawijaya (dalam Rosna, 2006:43) "belajar adalah proses pembinaan yang terus menerus terjadi dalam diri individu yang tidak ditentukan oleh unsur keturunan, tetapi lebih banyak ditentukan oleh faktor-faktor dari luar anak." Dalam belajar siswa banyak memperoleh dari guru, maka guru harus lebih memahami kembali ketiga aspek dalam pendidikan yaitu yang belajar, proses belajar dan situasi belajar. Yang belajar adalah anak didik atau siswa yang secara individu atau kelompok mengikuti proses pembelajaran dalam suasana tertentu.

Guru sebagai penggerak dan pengatur proses pembelajaran sudah seharusnya dapat mengaktifkan semua peserta didik tanpa terkecuali agar potensi yang ada pada siswa dapat tergali dan berkembang. Guru harus dapat memberikan motivasi kepada siswa dalam pembelajaran. Peran guru dalam membelajarkan siswa sangat besar, upaya menimbulkan motivasi siswa untuk belajar sangatlah berat seperti yang dinyatakan oleh Rochman (dalam Rosna, 2006:70) bahwa "memberikan motivasi siswa dengan mengenal setiap siswa secara pribadi”.

Perencanaan tindakan pada siklus 2 mencapai keberhasilan baik. Pada pelaksanaan tindakan sesuai dengan perencanaan. Pembelajaran pembagian pecahan pada siklus II ini, peneliti laksanakan sesuai dengan perencanaan dan langkah-langkah pembelajaran berbasis masalah sebagai berikut:

a. Mengorientasikan siswa pada masalah

Peneliti memajangkan kertas cart berisi permasalahan kontekstual yang berhubungan dengan perkalian bilangan asli dengan pecahan. Kemudian, meminta siswa membaca dan memahami masalah dengan melakukan tanya jawab yang berhubungan dengan masalah. pada tahap ini siswa sudah aktif dalam kegiatan tanya jawab. Sudah terlihat adanya timbal balik dari siswa dan guru. Siswa sudah menanggapi pertanyaan guru dan guru juga sudah menanggapi jawaban siswa. Dalam kegiatan ini sudah banyak siswa yang terlibat dan mereka sudah berpacu menjawab pertanyaan guru.

b. Mengorganisasikan siswa untuk belajar

Membagi siswa menjadi lima kelompok dengan anggota masing-masing kelompok 5-6. Untuk mempermudah siswa berdiskusi, guru membagikan LKS kepada masing- masing kelompok dan meminta siswa membaca dan memahami LKS. Kemudian, guru membagikan seperangkat alat yang digunakan untuk menyelesaikan masalah. Selanjutnya guru memotivasi siswa untuk aktif dan bekarja sama dalam kelompok. Pada tahap ini sudah terlihat siswa bekarjasama dalam kelompok dan sudah $80 \%$ siswa telah ikut bekarja dalam kelompok.

c. Membimbing penyelidikan individual atau kelompok

Siswa dibimbing berdiskusi untuk menyelesaikan masalah. Guru dan siswa melakukan tanya jawab tentang apa yang diketahui dan ditanya dalam permasalahan tersebut. Setelah itu, siswa dibimbing melakukan penyelidikan dengan menggunakan alat dan bahan yang telah disediakan. Dalam menggunakan alat siswa sudah nampak teliti, dan pada tahap ini, masing-masing kelompok sudah hanya 1 kelompok yang kurang 
benar dalam mengisi LKS dan siswa sudah menemukan langkah-langkah penyelesaian masalah dengan menggunakan benda-benda konkrit untuk melakukan pengujian.

d. Mengembangkan dan menyajikan hasil karya

Setelah siswa memanipulasi alat dan bahan yang disediakan, siswa membuat model matematika dari permasalahan tersebut. Dan mengisikan hasil kegiatan pada LKS. Kemudian siswa menyelesaikan masalah sesuai dengan langkah-langkah atau alternative pemecahan masalah yang telah direncanakan. Setelah selesai baru kemudian masing-masing kelompok melaporkan hasil diskusinya dan kelompok lain memberikan tanggapan. Pada tahap ini kelompok telah dapat mengaplikasikan tahap konkrit ke tahap semi konkrit. Kemudian 75\% kelompok sudah dapat menyelesaikan masalah kontekstual tersebut dengan benar.

e. Menganalisa dan mengevaluasi proses pemecahan masalah.

Setelah masing-masing kelompok melaporkan hasil diskusinya, guru bersama siswa mengoreksi masalah pemecahan masalah dan mengoreksi apakah tidak ada kesalahan dalam mengoperasikan angka. Dan 75\% kelompok sudah benar dalam menyelesaikan masalah. Setelah itu, guru memberikan penegasan terhadap hasil pemecahan masalah.

Berdasarkan hasil diskusi dengan guru kelas, maka diperoleh hal-hal sebagai berikut:

1. Penyajian materi dengan menggunakan SPBM sudah sesuai dengan rencana yang telah dibuat dan waktu yang digunakan untuk berdiskusi sudah dapat dimanfaatkan siswa dengan baik.

2. Guru sudah baik dalam memotivasi siswa untuk bekerjasama dalam diskusi dan sudah memberikan penghargaan kepada setiap jawaban-jawaban siswa sehingga siswa bersemangat untuk belajar.

3. Dalam berdiskusi $75 \%$ siswa sudah aktif manjawab, bertanya, dan bekerja dalam kelompok.

4. Kelompok terlihat sudah tidak kesulitan dalam mengisi LKS.

5. Hasil tes siklus I menunjukkan siswa sudah memahami materi yang diberikan. Sudah $75 \%$ siswa yang tuntas dalam belajar. Walaupun masih ada beberapa siswa yang masih mendapatkan nilai tes di bawah rata-rata.

Pada tahap pelaksanaan tindakan pada aspek guru sesuai dengan hasil pengamatan observer mencapai keberhasilan baik dan aspek siswa mencapai keberhasilan baik. Nilai rata-rata hasil belajar siswa pada pertemuan 1 yaitu 81,48 dan pertemuan II yaitu 79,63. Hasil belajar siswa pada siklus II mencapai nilai rata-rata 80,55. Dan ketuntasan belajar pada siklus II mencapai 77,78\%. Hasil belajar tersebut sudah mencapai standar ketuntasan yang telah ditetapkan sekolah yaitu $70 \%$.

Pembelajaran yang disajikan pada siklus II, yaitu guru dalam memberikan motivasi sangat bagus. Pada proses pembelajaran guru banyak memberikan kesempatan kepada siswa untuk berdiskusi bersama dan bertanya tentang permasalahan yang tidak dimengerti oleh siswa. Dan guru membimbing siswa dengan baik. Untuk itu guru harus mampu menciptakan situasi yang menyenangkan untuk belajar. Sehingga hasil belajar siswa meningkat.

Untuk mencapai hal tersebut sudah seharusnya guru mampu menciptakan pembelajaran yang sesuai dengan kebutuhan siswa. Guru bertugas membelajarkan siswa. Untuk membelajarkan siswa tersebut guru haruslah menggunakan berbagai macam cara agar pembelajaran dapat bermakna bagi siswa, seperti menggunakan pendekatan pembelajaran yang bervariasi, media pembelajaran yang sesuai dengan tujuan dan menciptakan suasana belajar yang menyenangkan bagi siswa.

\section{KESIMPULAN DAN SARAN \\ KESIMPULAN}

Paparan data dan hasil penelitian serta pembahasan di atas, maka peneliti dapat menarik kesimpulan dari penelitian ini yakni: Perencanaan Pembelajaran dengan menggunakan strategi pembelajaran berbasis masalah (SPBM) disesuaikan dengan langkah-langkah yakni: mengorientasikan siswa pada masalah, mengorganisasikan siswa untuk belajar, membimbing penyelidikan individual dan kelompok, mengembangkan dan menyajikan hasil karya, dan menganalisa dan mengevaluasi proses pemecahan masalah.

Pelaksanaan pembelajaran dengan SPBM dapat membuat siswa lebih aktif dalam belajar. siswa diajarkan untuk berdiskusi dalam memecahkan masalah, siswa dibimbing bekerjasama dalam kelompok. Sehingga pembelajaran lebih bermanfaat bagi siswa. Siswa dibimbing untuk menyelesaikan masalah secara sistematis. Keberhasilan aktivitas guru pada pembelajaran perkalian pecahan melalui strategi pembelajaran berbasis masalah pada siklus 1 mencapai keberhasilan baik dan aktivitas siswa mencapai keberhasilan baik. 
Pada siklus 2, aktifitas guru mencapai keberhasilan sangat baik dan aktivitas siswa mencapai keberhasilan sangat baik.

Meningkatnya hasil belajar siswa dapat dilihat dari hasil belajar siswa sebelum menggunakan SPBM yaitu 54,63 meningkat pada siklus I menjadi 72,02. Pembelajaran belum dianggap tuntas jika hasil yang diperoleh di bawah 75\% dan untuk itu penelitian ini dilanjutkan pada siklus II. Dan hasil belajar pada siklus II mengalami peningkatan menjadi 78,37.

\section{SARAN}

Berdasarkan kesimpulan yang telah dicantumkan di atas, maka peneliti mengajukan beberapa saran:

1. Untuk guru, agar dapat mencobakan dan menerapkan Strategi Pembelajaran yang lebih bervariasi dengan tujuan agar siswa dapat tertarik untuk mengikuti pelajaran yang diberikan

2. Bagi kepala sekolah dapat menganjurkan kepada guru untuk menerapkan bentuk pembelajaran ini, pada kelas yang lain .

\section{DAFTAR PUSTAKA}

Aderusliana, 2007, Konsep Dasar Evaluasi Hasil Belajar (online) http://aderusliana.wordpress.com/2007/11/05/konsep-dasar-evaluasi-hasilbelajar/ (diakses tanggal 2 Mei 2009).

Cholis Sa'dijah. 1999. Pendidikan Matematika II. Jakarta: Depdikbud.

Depdiknas. 2003. Undang-Undang Sistem Pendidikan Nasional (UUSBN). Jakarta. Depdiknas.

Depdiknas. 2006. Kurikulum Tingkat Satuan Pendidikan (KTSP). Jakarta: Depdiknas.

Ismail SM. 2008. Strategi Pembelajaran Agama Islam Berbasis PAIKEM. Semarang: RaSAIL Media Group.

Kunandar. 2007. Guru Profesional Implementasi Kurikulum Tingkat Satuan Pendidikan (KTSP) dan Sukses dalam Sertifikasi Guru. Jakarta: Raja Grafindo Persada.

Karso. 1998. Buku Materi Pokok Pendidikan Matematika I. Jakarta: Universitas Terbuka.

Muhammad Ali. 2004. Guru dalam Proses Belajar Mengajar. Bandung: sinar baru Algesindo.

M. Khafid. 2006. Matematika Untuk SD Kelas IV. Jakarta: Erlangga.

Mursal Dalais. 2007. Kiat Mengajar Matematika di Sekolah Dasar. Padang: UNP Press.

Nana Sudjana. 2002. Dasar-Dasar Proses Belajar Mengajar. Bandung: Sinar baru Algesindo.

Nafilah. 2008. Strategi dan Inovasi Pembelajaran Siswa SD. (online). http://nafilah.multiply.cosm/journal/item/26/ (diakses tanggal 5 Maret 2009).

Nurhadi dan Agus Gerrad Senduk. 2003. Pembelajaran Kontekstual (Contectual Teaching Learning/ CTL) dan Penerapannya dalam KBK. Malang: UM Press.

Oemar Hamalik. 2003. Kurikulum dan Pembelajaran. Jakarta: Bumi Aksara.

2003. Proses Belajar Mengajar. Jakarta. Bumi Aksara.

Ritawati Mahyuddin dan Yetti Iriani. 2008. Hand Out Mata Kuliah Metodologi Penelitian Tindakan Kelas. Padang: UNP.

Suwarna, Iwan Permana. 2008. Metode Mengajar Inkuiri. (online).

http://iwanps.wordpress.com/2008/04/17/ (diakses tanggal 5 Maret 2009). 
Sri Subarinah. 2006. Inovasi Pembelajaran Matematika di Sekolah Dasar. Jakarta: Depdiknas.

Sumiati dan Asra. 2007. Metode Pembelajaran. Bandung: Wacana Prima.

Suparyono. 2008. Pengertian Pembelajaran. (online). http://ayonganteng.blogspot.com/2008/01/ (diakses tanggal 26 Februari 2009).

Suryosubroto. 2002. Proses Belajar Mengajar di Sekolah. Jakarta: Rineka Cipta.

Tarmizi Ramadhan. 2008. Pembelajaran Aktif, Inovatif, Kreatif, Efektif, dan Menyenangkan. (online). http://tarmizi.wordpress.com/2008/11/11/ (diakses tanggal 5 Maret 2009).

Tim Pembina Matematika II. 2003. Silabus dan Hand Out Matematika II. Padang: UNP.

Vikto Pendrawarman. 2008. Peningkatan Hasil Belajar IPA melalui Metode Discovery pada Pembelajaran Gaya Magnet di Kelas V SD. Padang: FIP UNP. Skripsi.

Wina Sanjaya. 2008. Strategi Pembelajaran Berorientasi Standar Proses Pendidikan. Jakarta: Kencana Prenada Media Group. 